OPEN ACCESS

ISSN 2541-2841 (online) ISSN 2302-6790 (print)

Edited by: Didik Hariyanto

*Correspondence: Anisa Nurul Hasanah anisanurul777@gmail.c

Citation:

Hasanah, A. N., Yuniarti, E. Hidayat, D. (2021) Strategi

Public Relations PDAM

Tirtawening dalam Menanggapi Pengaduan Konsumen Melalui Media Sosial (Twitter), Kanal,

9(2).

Doi:10.21070/kanal.v9i2.1043

\section{Public Relations Strategy of PDAM Tirtawening in Responding to Consumer Complaints through Social Media (Twitter)}

\section{Strategi Public Relations PDAM Tirtawening dalam Menanggapi Pengaduan Konsumen Melalui Media Sosial (Twitter)}

\author{
Anisa Nurul Hasanah ${ }^{1 *}$, Elsa Yuniarti ${ }^{2}$, Dasrun Hidayat ${ }^{3}$ \\ 1,2,3Fakultas Ilmu Komunikasi dan Desain Universitas Adhirajasa Reswara Sanjaya
}

\begin{abstract}
The purpose of this study is to find out how PDAM Tirtawening's public relations strategy in responding to consumer complaints during the Covid-19 pandemic. After the Covid-19 pandemic, there were many changes ranging from social changes, community behavior actions, to changes in public services, especially in Pdam Tirtawening Bandung. This study uses descriptive studies with a skin-skinned approach. Data collection techniques in this study are observations, in-depth interviews with informants that have been determined by researchers consisting of 3 informants. Based on system theory by defining problems, planning and programming, communicating, evaluating this study found the fact that PDAM Tirtawening's Public Relations strategy during the Covid-19 pandemic is still receiving complaints, although the complaint is only submitted through social media twitter therefore PDAM Tirtawening strives as quickly as possible to respond to complaints and problems.

Keywords: Public Relation, Social Media, Covid-19.
\end{abstract}

\begin{abstract}
Abstrak
Tujuan dari penelitian ini yaitu, untuk mengetahui bagaimana strategi Public Relations PDAM Tirtawening dalam menanggapi pengaduan konsumen pada masa pandemi Covid-19. Setelah terjadinya wabah Pandemi Covid-19 ini, terjadi banyak perubahan mulai dari perubahan sosial, tindakan perilaku masyarakat, hingga perubahan pelayanan-pelayanan publik khususnya di PDAM Tirtawening Kota Bandung. Penelitian ini menggunakan studi deskriptif dengan pendekatan kulitatif. Teknik pengumpulan data dalam penelitian ini yaitu observasi, wawancara mendalam dengan informan yang sudah ditentukan oleh peneliti yang terdiri dari 3 orang informan. Berdasarkan teori sistem dengan mendefinisikan masalah, perencanaan dan pemograman, berkomunikasi, mengevaluasi penelitian ini menemukan fakta bahwa strategi Public Relations PDAM Tirtawening dimasa pandemi Covid-19 yaitu tetap menerima pengaduan, meskipun pengaduan tersebut hanya disampaikan melalui media sosial twitter oleh karena itu PDAM Tirtawening berupaya secepat mu-
\end{abstract}


ngkin untuk menanggapi pengaduan atau masalah.

Keywords: Hubungan Masyarakat, Media Sosial, Covid-19.

\section{PENDAHULUAN}

Keberadaan air bersih sangat penting bagi kesehatan dankebutuhan hidup setiap manusia, terutama di daerah perkotaan besar salah satunya Kota Bandung. salah satu perusahaan yang mengelola kebutuhan air bersih adalah PDAM Tirtawening Kota Bandung. Pada dasarnya tujuan PDAM yaitu memberikan pelayanan yang terbaik bagi seluruh konsumen pdam itu sendiri, dari segi produksi air dan pendistribusian air berstandar dan berkualitas. Dengan terus berkembangnya jumlah penduduk ke kota, menyebabkan tingginya kepadatan penduduk selaras itu diikuti pula peningkatan permintaan perumahan dengan sarana penunjang diantaranya pemasangan air baru danpelayanan air PDAM bagi konsumen yang teladan dengan melakukan pembayaran secara rutin. Sebagai perusahaan yang berorientasi pada layanan publik, PDAM harus dikelolah dengan baik, sehingga dapat memelihara kelangsungan hidup secara lancar dalam jumlah yang cukup. Kelancaran proses distribusi air yang dilakukan oleh PDAM di berbagai wilayah Kota Bandung tak sering juga mendapatkan keluhan dari berbagai konsumen, sehingga kurangnya kepuasan konsumen terhadap pelayanan PDAM. Dalam hal ini Pelayanan yaitu bagian terpenting dari suatu perusahaan, setiap badan usaha yang dikelola oleh pemerintah, baik pusat maupun daerah yang mempunyai tanggung jawab untuk memberikan pelayanan yang baik dan optimal kepada masyarakat. Dalam memberikan suatu pelayanan, perusahaan berusaha agar para konsumen bisa mempercayai visi dari PDAM titawening ini yang mempunyai tujuan meningkatkan pelayanan yang inovatif serta berteknologi.

Terkait dengan adanya wabah pandemi Covid-19, pemerintah menghimbau kepada masyarakat untuk mematuhi anjuran-anjuran dari pemerintah. PDAM Tirtawening sementara waktu tidak menerima kunjungan serta tamu karena untuk mengurangi nya resiko penularan Covid-19 dan sesuai Peraturan Walikota (PERWALI) Pembatasan Sosial Berskala Besar (PSBB) dan agar memutus rantai penularan Covid-19 (Perwali, 2020).

Cara berkomunikasi, seperti adanya keluhan, pengaduan serta saran dari berbagai konsumendapat dilakukan melalui daring atau media sosial seperti, twitter resmi pdam yaitu @ pdamtirtawening yang dikelola langsung oleh public relation PDAM. Oleh karena itu, Pentingnya seorang Public Relation pdam memiliki Strategi public relations. Strateg public relation dalam menjalin hubungan baik antara publik eksternal untuk menjaga keharmonisan dengan publik internal merupakan kewajiban yang harus dilakukan oleh staff public relations.

Hal ini membuktikan bahwa teknologi sangat berperan aktif untuk menyebarkan informasi dan berkomu- nikasi. Dengan hadirnya teknologi menjadikan salah satu faktor penghubung agar dapat saling berinteraksi dan memberi informasi kepada publik. Dalam penelitian ini, peneliti juga akan memaparkan beberapa teori yang berkaitan mengenai strategi. Strategi adalah suatu hal yang sangat penting bagi kelangsungan suatu perusahaan untuk mencapai misi dan visinya secara efektif dan efisien. Perusahaan harus mampu mengahadapi persoalan-persoalan baik dalam perusahaan maupun diluar perusahaan dan eksekusi dalam waktu yang tertentu.

Teknologi informasi dan komunikasi pertama kali dalam sejarah dimulai dengan tradisi media lisan berkomunikasi dengan cara verbal dan tulisan pada daundaun ataupun tanah liat. Tradisi cara penyampaian komunikasi dan informasi kemudian berkembang seiring dengan kelangsungan hidup atau yang kemudian dikenal dengan sebutan masyarakat modern. Dengan adanya media sosial yang bisa memudahkan aktivitas yang melibatkan sosialisasi dan jaringan online yang menggunakan kata-kata gambar dan video.

Media sosial menegaskan kembali bagaimana kita berhubungan komunikasi satu sama lain sebagai manusia dan bagaimana kita sebagai manusia bisa berhubungan baik dengan suatu organisasi atau perusahaan yang melayani kita.

Maka apabila media sosial telah mampu mengubah cara komunikasi masyarakat dengan lebih modern maka seorang praktisi public relations pun tidak boleh ketinggalan untuk memanfaatkan media sosial untuk mencapai visi dan misi perusahaan yang di wakilinya. Public relations telah mampu memanfaatkan media sosial untuk membangun relasi dan demi terciptanya hubungan yang harmonis antara perusahaan konsumen.

Twitter dapat dimanfaatkan sebagai sebuah media untuk komunikasi, menjaring teman, dan yang paling potensial adalah dapat digunakan untuk memasarkan produk. dalam twitter pengguna twitter (tweeps), tentu tahu bahwa jumlah pengikut (followers) (Damayanti, 2014).

Twitter yang digunakan untuk aktifitas pribadi, cukup komunitas teman-teman pengikutnya, namun jika akun twitter merupakan akun untuk web atau untuk toko online, maka membutuhkan lebih banyak pengikut di twitter.

Ada 3 riset yang dijadikan pijakan dalam penelitian ini. Salah satunya tentang strategi public relations dalam membangun citra yang dilakukan oleh Ambarwati (2009) di PT. Angkasa Pura Adi Sucipto Perbedaan riset tersebut dengan penelitian ini terletak pada objek penelitian dan pada fokus media public relations dalam membangun citra. Penelitian ini mengambil objek strategi public relations dalam berkomunikasi kepada konsumen.

Kemudian penelitian yang dilakukan oleh Andriani 
(2012) tentang strategi komunikasi humas PT. PLN distribusi Jawa Barat dan Banten melalui program sosialisasi web and call, secara umum kesamaan dalam penelitian ini tentang humas/public relations dan cara berkomunikasi.

Berdasarkan pemaparan diatas, peneliti tertarik untuk mengetahui bagaimana strategi komunikasi yang dilakukan oleh PDAM, dengan judul penelitian ilmiah "Strategi Public Relations PDAM Tirtawening dalam Menanggapi Pengaduan Konsumen Saat Pandemi COVID-19 Melalui Media Sosial (Twitter)". Penelitian ini bertujuan untuk: Mengetahui dan menganalisis public relations pdam terhadap proses mengidentifikasi masalah keluhan konsumen Mengetahui dan menganalisis public relations PDAM terhadap proses perencanaan dalam menanggapi keluhan konsumen, Mengetahui dan menganalisis public relations PDAM pada proses mengambil tindakan dan berkomunikasi pada saat menanggapi keluhan konsumen, Mengetahui dan menganalisis public relations pdam pada proses pelaksanaan evaluasi dalam menanggapi pengaduan keluhan konsumen.

\section{METODE PENELITIAN}

Dalam penelitian ini, peneliti menggunakan studi deskriptif, yaitu suatu metode penelitian yang dilakukan untuk memperoleh gambaran mengenai keadaan yang terjadi pada masa sekarang (Sugiyono, 2007).

Data didapat dengan teknik wawancara terbuka dan infoman ditentukan secara purposive. Sebanyak 3 (tiga) informan sesuai dengan kreteria, yaitu Heni Rahmawati bagian public relations PDAM, Deni Mulyana sebagai supervisor, serta Zulkifli konsumen wilayah Bandung Timur. Data yang didapat kemudian dianalisa menggunakan teknik reduksi data, penyajian data, dan penarikan kesimpulan. Setelah itu, dilakukan triangulasi sumber dan data untuk mengetahui keabsahan data.

\section{HASIL DAN PEMBAHASAN}

Pada awal ditemukannya virus Covid-19 di Indonesia, presiden dan para jajarannya menyampaikan untuk melakukan segala aktivias di rumah saja, mulai dari sekolah, bermain hingga bekerja di rumah. Kendati demikian, pelayanan-pelayanan publik seperti PDAM, harus tetap bertugas dan bekerja untuk melayani berbagai pengaduan serta menanggapi masalah yang terjadi pada konsumen. Oleh karena itu Public Relations dari pihak PDAM membuat akun sosial media@pdamtirtawening sebagai tempat pengaduan para konsumen, pihak PDAM membuat akun @ pdamtirtawening agar konsumen tidak perlu untuk pergi keluar rumah di masa wabah Covid-19. Pemilihan media twitter dirasa tepat karena sesuai dengan kebutuhan PR PDAM. Twitter adalah suatu situs web yang merupakan layanan dari microblog, yaitu suatu bentuk blog yang membatasi ukuran setiap posnya, yang memberikan fasilitas bagi pengguna untuk dapat menuliskan pesan dalam twitter update hanya berisi 140 karakter.

Menurut Zarela dalam Setyani (2013) twitter merupakan salah satu jejaring sosial yang paling mudah digunakan, karena hanya memerlukan waktu yang singkat tetapi informasi yang disampaikan dapat langsung menyebar secara luas. Menurut catatan resmi yang dikeluarkan twitter sendiri, lebih dari 100 juta pengguna telah memposting setidaknya 340 juta kicauan per hari, pada 2012. Setahun kemudian, twitter disebut masuk 10 besar situs dunia yang paling banyak dikunjungi. Dari sekian banyak pengguna twitter, Indonesia memiliki peran berarti. Pada 2010, Indonesia menempati peringkat pertama dilihat dari sisi pertumbuhan nya. Pada tabel tahun-tahun selanjutnya Indonesia masih menempati lima besar dunia dalam hal pengguna twitter.

Keberadaan public relations dalam sebuah corporate atau instansi dapat menjadi jembatan penghubung antara organisasi atau perusahaan tersebut dengan publiknya. Pada dasarnya tujuan dari seorang public relations yaitu menciptakan, memelihara, dan membina hubungan yang baik dengan kedua belah pihak yakni organisasi atau perusahaan dengan publiknya (Deavani, 2019).

Fungsi public relations yaitu menumbuhkan hubungan baik antara segenap komponen pada suatu lembaga perusahaan dalam rangka memberikan, menumbuhkan motivasi dan partisipasi. Adapula external public relations, adalah publik umum (masyarakat) yang berada di luar perusahaan atau organisasi. Publik eksternal yang menjadi sasaran public relations yaitu para pelanggan (customer), khalayak sekitar (community), instansi pemerintah (government), pers (press) dan lain lain kelompok yang berada diluar organisasi (Uchjana, 2009).

Peneliti melakukan observasi dan wawancara kepada staff public relations serta supervisor PDAM Tirtawening. Dalam hal ini peneliti akan memaparkan hasil temuan yang ada dilapangan mengenai proses mendefinisikan problem pihak public relations PDAM Tirtawening, supervisor PDAM Tirtawening. Menurut penjelasan Heni Rahmawati selaku supervisor, sebelum terjun langsung ke lapangan, pihak PDAM Tirtawening melakukan pendataan informasiinformasi, yang berupa pengaduan atau keluhan masalah para konsumen, setelah itu barulah petugas lapangan mendatangi para konsumen.

Pihak PDAM Tirtawening berusaha agar dapat dengan cepat merespon berbagai pengaduan dari para konsumen, selanjutnya akan diproses dan pihak PDAM akan menindaklanjuti laporan satu hari setelah adanya laporan pengaduan dari konsumen.

Teori sistem merupakan dasar kehidupan manusia. Teori sistem memfokuskan perhatian untuk memahami bagaimana kualitas fungsi yang dijalankan setiap sistem dalam suatu relasi dinamis dengan sistem-sistem lainnya (Sugiyono, 2007). 
Teori sistem memfokuskan perhatian untuk memahami bagaimana kualitas fungsi yang dijalankan setiap sistem dalam suatu relasi dinamis dengan sistem-sistem lainnya (Kriyantono, 2017). Dengan kata lain, teori sistem ini menjelaskan tentang pentingnya menjalin hubunga sosial. Menjalin hubungan sosial yang baik merupakan hasil dari suatu interkasi sosial, dalam hal yaitu interaksi antara organisasi dengan publik.

Mendefinisikan masalah, merupakan sebuah proses untuk mencari dan mendefinisikan atas suatu masalah yang terjadi ataupun sedang dihadapi oleh suatu perusahaan sebagai dasar acuan untuk menyusun langkah selanjutnya, pada tahap ini sering disebut dengan kegiatan penelitian.

Perencanaan dan pemrograman, merupakan pemilihan atau menetapkan tujuan organisasi dan menentukan strategi, kebijaksanaan, program, prosedur, metode, dan sistem yang dibutuhkan dalam pengelolaan akun media sosial twitter @ pdamtirtawening perlu merancang suatu program atau perencanaan tertentu agar dapat mengetahui tujuan dari setiap program dan cara mencapainya.

Mengambil tindakan dan berkomunikasi, pada tahap ini lebih menekankan pada proses pelaksanaan. Humas PDAM Tirtawening dalam menanggapi pengaduan pelanggan saat adanya wabah covid-19, hanya menanggapi pengaduan melalui media sosial twitter @ pdamtirtawening, meskipun pelanggan membuat pengaduan melalui media sosial twitter, pihak public relations PDAM akan berupaya agar secepat mungkin untuk bertindak dan mengkomunikasikan dalam mencapai tujuan.

Mengavaluasi program, merupakan penilaian atas persiapan, implementasi, dan hasil dari program yang telah dilakukan. Proses evaluasi dalam suatu perusahan sangatlah penting untuk mengukur perkembangan suatu perusahan dan meningkatkannya menjadi lebih baik dari pada yang sebelumnya.

Untuk membuktikan efektivitas twiter sebagai media pengaduan, peneliti mewawancarai konsumen PDAM Tirtawening. Menurut informan, pengaduan dengan menggunakan bantuan media sosial twitter sangatlah efektif dimasa pandemi covid-19 ini, serta mencegah penularan virus tersebut, sehingga para konsumen tidak perlu datang ke kantor pelayanan PDAM.

Pandemi Covid-19 ini mengakibatkan kecemasan semua orang, namun pelayanan publik harus tetap berjalan, sehingga hampir semua pelayanan publik menggunakan media daring baik untuk memberikan informasi atau untuk para konsumen melaporkan pengaduan masalah air. Hal ini dikarenakan karena adanya kebijakan dari pemerintah agar menggunakan media daring untuk menghindari penyebaran virus Covid-19. Oleh karena itu banyak pelayanan publik yang menggunakan media sosial guna menanggapi keluhan dari masyarakat atau konsumen. Salah satu pelayanan publik yang menggunakan media daring untuk menerima pengadu- an masalah yaitu, PDAM Tirtawening menggunakan media sosial twitter. Pihak PDAM Tirtawening tetap menerima pengaduan pelayanan melalui media sosial twitter, meskipun para konsumen hanya dapat melaporkan masalahnya melalui media daring, tetapi pihak PDAM Tirtawening berupaya merespon serta menanggapi masalah-masalah yang terjadi dan keluhan masalah yang di laporkan oleh para konsumen, dengan demikian PDAM Tirtawening akan memberikan pelayanan dengan tepat.

\section{KESIMPULAN}

Berdasarkan hasil penelitian yang telah dilakukan oleh peneliti, untuk mengetahui bagaimana strategi Public Relations PDAM Tirtawening dalam menanggapi pengaduan konsumen pada masa pandemi Covid-19. Pada bagian akhir ini peneliti akan memaparkan beberapa kesimpulan yang dapat diambil berdasarkan penelitian yang telah dilakukan dan dianalisis, maka peneliti menarik kesimpulan, bahwa tidak terjadi perubahan/perbedaan disaat sebelum dan sesudah adanya pandemi Covid-19 karena pelayanan akan terus berjalan, meskipun memang tidak secara langsung untuk melakukan pengaduan konsumen pihak PDAM Tirtawening akan terus tetap melayani dengan sigap. Sebagai mana dikatakan karena kita membutuhkan yang cepat, akurat serta bisa dipertanggung jawabkan menjadikan media sosial ini sebagai salah satu media utama dalam pencarian informasi dan media komunikasi. Staff public relations selalu mengkomunikasikan dengan baik dengan memberikan penjelasan informasi yang cepat kepada konsumen, lalu juga pihak public relations menghubungi bagian wilayah agar segera di tindak lanjuti atas keluhan konsumen tersebut. Terbukti pula bahwa media sosial sangatlah berpengaruh banyak dalam proses berkomunikasi dengan situasi/kondisi saat ini, sosial media telah merevolusi kecepatan informasi atau berita. Banyak organisasi atau kantor berita yang bergantung pada sosial media untuk mengumpulkan dan membagikan informasi. Kini Twitter telah menjadi sumber utama bagi masyarakat dan juga kita semua untuk mendapatkan berita untuk memberikan pendapat. Dan Siapapun dapat mengetahui apa saja yang sedang terja di di seluruh dunia secara real-time dengan penggunaan sosial media.

\section{UCAPAN TERIMAKASIH}

Terima kasih kepada civitas akademika ARS university terutama Dr. Dasrun Hidayat, M.I.Kom selaku Dekan Fakultas Komunikasi dan Desain ARS University yang telah mendukung penelitian ini. Terima kasih juga disampaikan kepada redaksi Kanal: Jurnal Ilmu Komunikasi yang telah bersedia memuat artikel ini.

\section{REFERENSI}

Ambarwati, K. (2009). Peran Dan Strategi Public Relations Dalam Membangun Citra. Skripsi. Universitas Islam Negeri Sunan Kalijaga Yogyakarta Damayanti, E. T. (2014). Pemanfaatan Twitter Sebagai Media Informati- 
on Sharing di Perpustakaan. Skripsi. Universitas Airlangga.

Deavani, Bayu K. (2019), Strategi Public Relations dalam Pengelolaan Media Sosial PT. Kereta Api Indonesia. Skripsi. Bandung: Universitas Pasundan.

Kriyantono, Rachmat. (2014). Teori Public Relations. In Public Relations Perspektif Barat \& Lokal. Jakarta: Kencana.

Indri, A. (2012). Strategi Komunikasi Humas PT.PLN. Universitas Kristen Petra Surabaya.

Peraturan Walikota. (2020). Pelaksanaan Pembatasan Sosial Berskala Besar Dalam Penanganan Corona Virus 2019.

Setyani, Nomorvia Ika. (2013). Pengguna Media Sosial Sebagai Sarana Komunikasi Bagi Komunitas. Jurnal Komunikasi, (online). Surakarta. Universitas Sebelas Maret.2013. https://abdulkaharkimia.files.wordpr ess.com/2013/12/jurnal-novia-ika.pdf.

Sugiyono. (2007). Metode Penelitian Kualitatif dan R\&D. Bandung: Alfabeta.

Uchjana, Onong, E. (2009). Humas Relations \& Public Relations. Bandung: CV. Mandar Maju.

Conflict of Interest Statement: The authors declare that the research was conducted in the absence of any commercial or financial relationships that could be construed as a potential conflict of interest.

Copyright $(2021$ Hasanah, et.al.Thisisan open-access article distributed under the terms of the Creative Commons Attribution License (CC BY). The use, distribution or reproduction in other forums is permitted, provided the original author(s) and the copyright owner(s) are credited and that the original publication in this journal is cited, in accordance with accepted academic practice. No use, distribution or reproduction is permitted which does not comply with these terms 